\title{
Intensity Heterosis Effect in Squash Cucurbita Pepo L.conv. giromontia Alef.
}

\author{
Maria DUMITRU ${ }^{1 *}$, Gicuta SBIRCIOG ${ }^{1}$, Iuliana MANDRU1 and Alina BUZATU ${ }^{1}$ \\ ${ }^{1}$ Research and Development Institute for Vegetable and Flower Growing-Vidra, Romania \\ *)Corresponding author, e-mail: maria.dumitru55@yahoo.com
}

BulletinUASVM Horticulture 72(2) / 2015

Print ISSN 1843-5254, Electronic ISSN 1843-5394

DOI:10.15835/buasvmcn-hort:11472

\begin{abstract}
In order to establish heterosis the squash, advanced homozygous lines were created, on contrasting characters studied. The Cucurbits were among the first vegetable species whereat hybrid seed was commercially produced (Borghi, 1971). In Cucurbits it can be use the $\mathrm{F}_{2}$ generation seed without recrossing to manual pollination with the condition that the genitors have similar characters that are important for the consumers. Five lines were obtained that were included in diallel crosses, a program to determine the specific combination ability. Through multiple comparisons method the 15 genotypes were grouped into six groups in which no significant differences. Studied hybrids exceeded both genitors and best genitor in terms of yeld capacity, surpassed by differences statistically very significant. Heterosis, complex biological phenomenon, was manifested in all hybrid combinations what was studied, consagvinizate used as genitors lines were different in terms of the characters analyzed, enabling the body assembly of a complex hybrid of useful traits. The significance of differences was determined by analysis of variance (Ceapoiu, 1968). It was calculate the limit differences and was applied the multiple comparison method (Duncan test). Analysis of variance for studied character it has showed that between the genotype are semnificative differences: $\mathrm{F}$ value (that has been calculate 44.86 it's bigger that theoretical $\mathrm{F}$ value.
\end{abstract}

Keywords: Cucurbita pepo, hybrid, heterosis.

\section{Introduction}

The Cucurbits were among the first vegetable species whereat hybrid seed was commercially produced (Borghi, 1971). This was due to the possibilities of obtaining enough vigorous maternal lines as a result of the weak inbreeding depression at these species, as well as to the easiness of doing the controlled pollination and to the high amount of seeds, obtained from a single cross (Grebenscicov, 1967). In Cucurbits it can be use the $\mathrm{F}_{2}$ generation seed without recrossing to manual pollination with the condition that the genitors have similar characters that are important for the consumers.

\section{Aims}

The aim of paper is to highlight the behaviour of $F_{1}$ squash hybrids obtained in the RDIVFG our breeding program in order to identify possible hybrid combinations promoted on a large scale.

\section{Materials and Methods}

The research work began in 2004 by creating homozygous lines, contrasting on plant size, shape and colour of fruit. Five lines were obtained that were included in diallel crosses, a program to determine the specific combination ability. In 2009, the ten hybrids which were obtained was studied in three replicates CCO. The significance of differences was determined by analysis of variance (Ceapoiu, 1968). It was calculate the limit differences and was applied the multiple comparison method (Duncan test).

\section{Results and Discussion}

Analysis of the results show that the magnitude of heterosis ranged between $51.9 \%(\mathrm{H} 4)$ and 1.5 \% (H10). It is demonstrate that the line L174 has the highest capacity combination, yield hybrids with most highly significant heterosis effect. Through multiple comparisons method the 15 
Tab.1. Analysis of variance for productivity in the system diallele squash, RDIVFG Vidra

\begin{tabular}{cccccc}
\hline Variation source & SPA & GL & $S^{2}$ & F \\
\cline { 1 - 4 } Blocks & 11.52 & 2 & 5.76 & & \multirow{2}{*}{$44.86^{* *}(1.97 ; 2.62)$} \\
\cline { 1 - 4 } Lines & 4.239 .65 & 14 & 302.83 & & \\
\hline Error & 189.15 & 28 & 10.75 & \\
\hline Total & 4.440 .32 & 44 & 100.91 & \\
\hline
\end{tabular}

Tab.2. The behavior of $\mathrm{F}_{1}$ hybrid forms and parents to squash, RDIVFG Vidra

\begin{tabular}{|c|c|c|c|c|c|}
\hline Genotype & Yielding capacity(t/ha) & $\mathrm{p}$ & $\mathrm{q}$ & $\mathrm{Rp}-\mathrm{q} \times \mathrm{s}$ (t/ha) & Significance of differences \\
\hline $\mathrm{H}-2$ & 83 & - & - & - & $\mathrm{a}$ \\
\hline $\mathrm{H}-4$ & 79 & 2 & 2.89 & 4.306 & $\mathrm{ab}$ \\
\hline H-15 & 77 & 3 & 3.84 & 5.185 & $\mathrm{bc}$ \\
\hline $\mathrm{H}-5$ & 73 & 4 & 3.84 & 5.72 & $\mathrm{~cd}$ \\
\hline $\mathrm{H}-3$ & 71 & 5 & 4.11 & 6.12 & de \\
\hline $\mathrm{H}-7$ & 69 & 7 & 4.30 & 6.407 & de \\
\hline $\mathrm{H}-17$ & 67 & 6 & 4.46 & 6.645 & ef \\
\hline $\mathrm{H}-12$ & 67 & 8 & 4.60 & 6.854 & ef \\
\hline $\mathrm{H}-16$ & 64 & 9 & 4.72 & 7.033 & $\mathrm{f}$ \\
\hline $\mathrm{L}-105$ & 63 & 10 & 4.83 & 7.196 & $\mathrm{f}$ \\
\hline H-6 & 57 & 11 & 4.92 & 7.330 & g \\
\hline L-184 & 56 & 12 & 5.00 & 7.45 & gh \\
\hline L-161 & 55 & 13 & 5.08 & 7.569 & gh \\
\hline $\mathrm{L}-200$ & 52 & 14 & 5.15 & 7.673 & hi \\
\hline $\mathrm{L}-174$ & 51 & 15 & 5.21 & 7.762 & $\mathrm{i}$ \\
\hline
\end{tabular}

genotypes were grouped into six groups in which no significant differences. Sintesis of the obtained results regarding the intensity of heterosis effect, and the behaviour of some hybrid $\mathrm{F}_{1}$ compared with the paternal forms are presented in the table 1 and 2 . Analysis of variance (table 1) for studied character it has showed that between the genotype are semnificative differences: $F$ value (that has been calculate 44.86 it's bigger that theoretical $\mathrm{F}$ value.

From table 2 were it is shown that multiple comparation between analized genotypes it can be concluded that the smallest limit difference for $\mathrm{P}=5 \%$ has a value of 4.306 , very closed to the one obtained from regular T test (4.53). Because of this, it can be told that the number of cases where the differences are statistic assured, to be very similar.

\section{Conclusion}

Studied hybrids exceeded both genitors and best genitor in terms of yeld capacity, surpassed by differences statistically very significant. Consagvinizatelineswereused as genitorslines were different in term of characters analysis, allowing the assembly of a complex hybrid organism with useful traits. Heterosis, complex biological phenomenon, was manifested in all hybrid combinations what was studied, consagvinizate used as genitors lines were different in terms of the characters analyzed, enabling the body assembly of a complex hybrid of useful traits.

\section{References}

1. Borghi B (1971).Produzione di sementi ibride delle Cucurbitaceae straverso la regolazione dell espression sessuale. Sem.Elette 2:27-32.

2. Ceapoiu N (1968).Statistical methods in agricultural and biological experimants. Ed.Agro-Silvică, București.

3. Anido FL, Cravero V, Asprelli P, Firpo T, Maris S, Cointry E (2004). Heterotic patterns in hybrids involving cultivargroups of summer squash, Cucurbita pepo L.. Euphytica, Volume 135:355-360.

4. Grebenscicov I (1967). Zur quantitativ - genetisches. Analyse der Ertragskom-ponenten

5. beim Kürbis. Teil 3 : Reziproke Kreuzung zweier stark verschedener Typen von C.maxima. Die Kulturpfl.

6. Kasrawi MA (1994). Heterosis and reciprocal differences for quantitative traits in summer squash (Cucurbita pepo L.). Journal of Genetics and Breeding, Volume: 48, Pages: $399-404$. 